\title{
Poetic Syntax as a Means of Writer's Idiostyle (by the example of S.S. Vasilyev-Borogonsky works)
}

\author{
Varvara E. Stepanova ${ }^{1}$, Lidiya E. Manchurina ${ }^{2 *}$ \\ ${ }^{1}$ Institute of A. Kulakovsky, NEFU, 58 Belinsky str, Yakutsk, 677000, Russia \\ ${ }^{2}$ Institute of Languages and Cultures of the Peoples of the Northeast of the Russian Federation, NEFU, \\ 58 Belinsky str, Yakutsk, 677000, Russia
}

\begin{abstract}
The article is devoted to the study of writer's individual style. It is carried out using linguostylistic analysis of the linguistic as well as stylistic and textual features typical for his works. In total, over 200 poems by Sergei Vasilyev-Borogonsky were analyzed, including verses and poems. Linguistic and stylistic as well as textual facts are based on 500 lines of poetry. As a result of the study, it was revealed that the idiostyle of the writer is mainly manifested at the syntactic level. At this level, the syntactic and semantic-syntactic means are distinguished, represented by stylistic figures and syntactic constructions. The most common syntactic means are the types of repetitions that create the rhythmic organization of the poetic text (anaphora, epiphora) and some syntactic constructions that testify to folklorism and high pathos of the stylistics of works (syntactic parallelism, rhetorical questions, addresses and exclamations). Both semantic and syntactic means are found in the continuous connection of repetitions structure with their semantics (antitheses, gradations and refrains). By means of poetic syntax, S.S. Vasilyev-Borogonsky creates artistic images, reveals the themes and ideological intentions of his works, and creates author's lyrical digressions. They also serve as a means of creating the composition and rhythm of a poetic text. The novelty of this study results from the fact that the language and style of the Yakut poet and publicist, Sergei Vasilyev-Borogonsky, has not yet become an object of special study.
\end{abstract}

\section{Introduction}

The language of works by famous Yakut poet S.S. Vasilyev is distinguished by his expressiveness, bright journalism, an abundance of folklore formulas and a variety of stylistic techniques.

The characteristic feature of the poetry of S.S. Vasilyev, in both artistic and aesthetic terms, is the nationality of the language, i.e. stretched epic sentence structures, enriched with rhetorical and syntactic figures. Special study of the poetic language of S.S. Vasilyev's works from the point of view of syntax makes it possible to identify his individual style, based on the desire to preserve epic codes in the structure and images of his works.

When studying the peculiarities of the language, one of the main areas is the study of stylistic techniques and means of expressiveness used to create an image convey the idea of work, as well as to construct a poetic text as a whole. In the works of the outstanding researcher M.M. Bakhtin, it is proved that it is in the language of the writer's work that 'the spiritual creativity of the individual' is manifested and the author's personal attitude to the described image is expressed [1, p. 246]. G.O. Vinokur studies the features and role of syntactic figures and stylistic means. One of the main provisions in his works proves that the study of this issue makes it possible to trace the evolution of the author's style at all stages of the writer's work [2, p.185].

Modern research on the poetic language of individual works of writers testifies to the importance of studying the syntactic figures, stylistic devices and means. Thus, at the level of structural-compositional, semantic consideration of a literary text, it is possible to determine the factors of idiostyle, skill and innovation of the writer $[3,4,5]$.

Yakut literary scholars carry out meticulous work as regards the analysis of the poetic language. They identify the features of the use of pictorial and expressive means and tropes, folklore formulas in the works of art of Yakut poets. In the works of N.N. Toburokov, P.V. Maximova, V.B. Okorokova, N.V. Pokatilova, V.G. Semenova, L.N. Romanova, E.A. Arkhipova et al., the features of the use of stylistic means and techniques based on the study of the work of the classics of Yakut literature are considered.

The figures of the author's speech in the works written by S.S. Vasilyev on the topic of the Great Patriotic War were considered by N.Z. Kopyrin. The researcher revealed the peculiarities of the use of anaphoric repetitions, rhetorical figures, syntactic and stanzaic parallelisms in the poet's journalistic lyrics. He argues that the poet's abundant use of parallelisms and repetitions directly indicates the folklorism of his work [6, p. 96-101]. For the folklore texts, the abundance of 
repetitions is a characteristic phenomenon, which is indicated in the fundamental works of G.M. Vasilyev, N.N. Toburokov, M.N. Dyachkovskaya. They clarify that repetitions, as one of the main verse-forming elements in an epic text, give it a rhythmic order $[7 ; 8]$.

\section{Results and Discussion}

Anaphora and epiphora are the main types of repetitions in a literary text, techniques for constructing a composition and the rhythmic organization of a poetic text. Units of any speech levels can be repeated: sound, word, phrase and sentence. In poetics and stylistics, anaphora is understood as a method of organizing a poetic text, when exact repeated sounds, identical words or identical expressions are placed at the beginning of adjacent verse lines or stanzas [9, p. 55-57]. According to the principle of the appearance and design of repetitions in the text, such types of anaphores are distinguished as sound, lexical, syntactic, stropic, stropic-syntactic, rhythmic and pause monotonies.

In the poetic heritage of S.S. Vasilyev the main types of anaphora are used, among them are as follows: lexical, syntactic, stropic monotony, which mainly perform a verse-forming function when creating a poetic text. Anaphoric repetitions are represented by the same words in the sentences or combinations used in the same grammatical form. The poet uses the anaphora technique to enumerate and make the depicted images more specific as well as to enhance the meaning of abstract concepts: Min taptalym/KYlymnYYr kyn Kurduk sylaas, / Min taptalym / KYndeerer hallaan Kurduk yraas [8. c, 74] (My love / Is as warm as a sparkling sun, / My love / Is as pure as a clear sky) (hereinafter, the translation is made by S.V., M.L.).

In S.S. Vasilyev's works the number of stanzaic anaphores significantly exceeds the number of lexical monotonies. This type of repetition gives the poetic texts a special expression and emotional nature. The poem Min khaiam (My Mountain, 1938), represented by anaphoric phrases 'min khayam' (my mountain), lists the properties of the mountain that the poet identifies with his native land and is conveyed by him in a spiritually agitated intonation. The poet, with stanza anaphores, refreshes his position on some issue: Poet en sanaajyn YerYynen oyuuluur, / Poet en kynakkyn kyoh kuorsunnuur! / Poet en dyegin yryanan archylyyr, / Poet en takhsar kun aikhallyyr! [11, p. 79] (The poet adorns your soul with joy / The poet feathers your wings! / The poet protects your house / The poet welcomes your morning!).

The most significant stylistic device in the poetry of S.S. Vasilyev is epiphora. These repetitions, similarly to anaphora, perform the function of creating the harmony of the poetic text, as well as to enhance the emotional coloring of literary texts. There are three types of epiphores: phonetic, lexical, and syntactic [9, p. 511]. End repetitions of sounds in the creative heritage of S.S. Vasilyev and other Yakut poets are numerous, since as a result of selections of homogeneous sounds, simple phonomorphological rhymes are created, where rhyming words are represented in the same grammatical form. S.S. Vasilyev's lexical epiphores are aimed at ensuring the high intonation of the work. Repetitive words and phrases in turn form a tautological rhyme in poems.

As a result of analysis of the repetitions used by S.S. Vasilyev, there were identified three types of monotonies and terminal repetitions, while it can be emphasized that the poet uses repetition techniques, mainly as a means of enhancing the expressiveness of the rhythm of poetic works. With the help of various repetitions, other techniques of poetic syntax are created, for example, gradation and refrain. The initial and final repetitions of words are found in all poetic works, regardless of the period of his creative activity, which emphasizes special originality of the poetic style of S.S. Vasilyev.

Syntactic parallelism as a stylistic device is a compositional device that emphasizes the 'structural relationship between two or three elements of style in the work of art', equally located similar members of a sentence or segments of speech [9, p. 306]. According to the generally accepted classification, parallelisms are complete or partial. Full parallelisms differ by the fact that the members of sentences in parallel constructions have the same grammatical form.

In the works of Yakut folklorists, the concept of parallelism is interpreted as a stylistic device composed of parallel sentence constructions that play a role in the construction of the composition of an epic text [12, p. 162] Specialist in the field of poetry, M.N. Dyachkovskaya, points out that parallel constructions are found in the texts of folk lyrics and olonkho, which are simple rhymes [8, p. 25-34]. Syntactic parallelism is a feature not only of the Yakut folklore text, but also a characteristic feature of the poetics of Turkic versification [13, 14]. At the same time, it was established that in the Yakut storytelling tradition, rhythmic-syntactic parallelism is the main organizing unit of olonkho formulas, in which 'keywords and phrases form the basis surrounded by the elements subject to variation' [15, p. 214].

In the works of S.S. Vasilyev, the techniques of syntactic parallelisms often perform the function of forming an integral poetic image. At the same time, homogeneous parallel structures are used to convey a gradual, sequential perception of the image: Kokhsyger / KYr muus kolohynneh, / Inniger / Ilir kyahaan ilbirgesteh. / Battagar / Barcha haar kyryalaakh, / Bytygar / Bylas kyrya bytyrystah, / Atagar / Adaar char adagalaakh, / Kharytygar / Khalyr muus kyagaannaakh / Kyrdyagas / Moruos o5onnor өndөнn soot [16, p. 101] (On the back / Icy sweat, / In front / Hanging from icicles. / Hair / With snow frost, / With a long beard / From a snowy fringe, / On my feet / Protruding iron pads, / On my arms / Ringing ice / Honorable / Father Frost tries to get up).

Parallel lines, consisting of homogeneous members of the sentence, create a phonomorphological rhyme, thereby achieving the sound and rhythmic ordering of the poem. This phenomenon, typical for epic texts, is traced into the poet's literary texts. 
Strophic parallelisms contribute to the construction of the composition, the description of the development of the plot of the work:

\section{Boo suolunan}

Kygyl Moskvattan

Kyraai Sakha Siriger

Kylbayar sytyy sidyk

Kyymnyy yhylybyta ...

\section{Boo suolunan}

Hotun Lenam

Khorsun ichchattara,

Kylaannaah kylygy

Kylbachchi tupputunan,

A5a doidunu kemyskyY,

Ar5aa aaspyttara ... [10, c. 222]

The abundant use of syntactic and stanzaic parallelisms in poetry is a hallmark of the individual style of S.S. Vasilyev, formed on the basis of folklore sources. Parallelisms in the works of the author focuse the attention on artistic images, explanations, a detailed description of their internal qualities and characteristics of external data, etc.

One of the favorite techniques of S.S. Vasilyev is an antithesis as 'a stylistic figure of contrast, sharp opposition of concepts, positions, images, states, etc. in artistic or oratory speech' $[9$, p. 61]. The contrasting techniques used by the poet not only enhance the expressiveness and imagery of the work, but also confirm the folklorism of his creative heritage. This can be seen in the text abstract of S.S. Vasilyev: Ikki kYYs - / Syrdyk uonna hara kYYs, - / Epsari tusyhen, / Ellehen istilar, / Hardary annyhan, / Khaannahan bardylar ... [10, p. 149-150]. (Two powers: The light against dark power, In a strong fight, Spreading themselves, they pushed forward, They began to fight until they bleed ...). The formal expression of folklore, used by the poet, not only reveals the contrasting images of two warring armies, but also resembles the image of the beginning of the struggle of aiyy hero against abaasy. Words with the opposed meaning sydyk (light) - kharara (dark) are often found in the texts of the Yakut heroic epic olonkho and prove the epic style of the poet's works.

Using the antonymic verbs 'bar-kel' (leave-come), a storyline is described that reveals the travel of the lyric hero of the ballad Ytyk Ilmen (Sacred Ilmen, 1967) to the distant Novgorod region:

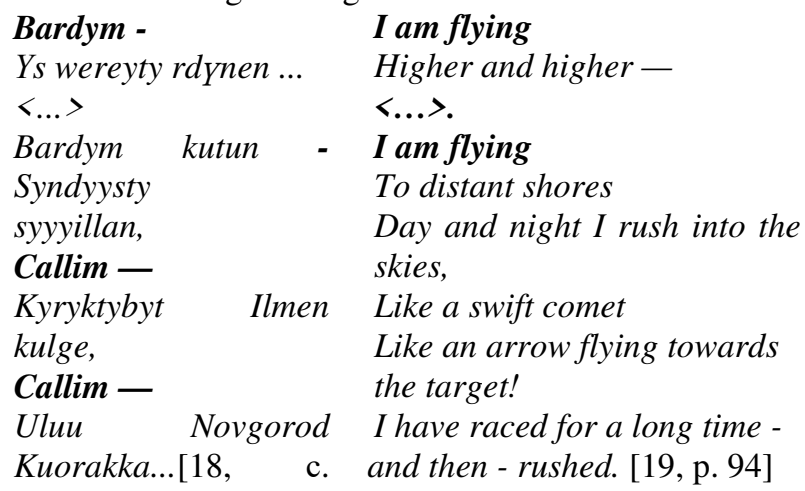

\section{Translated by $S$.} Severtsev

In the poetry of S.S. Vasilyev, the examples of the method of semantic contrast are used. As L.E. Manchurina notes, the antitheses method used by S.S. Vasilyev could stretch out and cover the whole parts of the work. In this regard, a poetic work was created, consisting of four parts 'In the forest where the battle took place'. The poet contrasts the first and second parts of this work, where, with the help of contrast, a beautiful landscape of a forest thicket in peacetime is described and a picture of a collapsed forest after a battle is depicted [19, p. 84]. The poet introduces a complicated antithesis, which takes up a larger volume of the text of the work. At the same time, contrasting images are captured by other syntactic techniques and means of artistic expression, for example, metaphor and personification. Thus, the analysis of the use of antitheses indicates that this technique in the poet's work is one of the leading ways to ensure the artistic expressiveness of poetic images.

The main feature of the poetic language of the works of S.S. Vasilyev is the frequent use of rhetorical figures in the form of questions, addresses and exclamations. The poet's favorite stylistic figures not only serve as a way to convey the ideological content of a literary text, but also to enhance the emotional and expressive saturation of the work.

The techniques of rhetorical addresses and questions are used in poetic works, which include dialogues and monologue speech. As a result of the skillful use of rhetorical figures, lyricism, author's emotional state, and artistic expressiveness are directly enhanced.

The addresses of the hero of the lyric works of S.S. Vasiliev are aimed at his beloved: En, taptyyr kyyhym, khanna syldyagyn? / Eder syrekhhin tugunan aalakyn? [10, p. 28] (You, my beloved girl, where are you now? / What are your worries about?). The feeling of loneliness or unrequited love is described in parallel with natural phenomena. Consequently, rhetorical appeals are also addressed to the objects of the surrounding world, such natural phenomena as a mountain range, river waves, clouds, wildflowers, and a variety of birds. In the poem Tyal (Say the Wind) S.S. Vasilyev expresses the joyful mood of the lyrical hero, overflowing with love and happiness, with the help of the poetic image of the wind. The author in all four stanzas uses rhetorical questions addressed to the wind: Tо5о, menik tyalchaan, / Tohtoobokko sYyrekelii syldyagyn? / <...> / Khaya min taptaabyt dyakhtarbyn / KYYskYnen kuuspalaan keeltik buolaaray? [8, p. 88] (The breeze is playful, careless, / Why are you running around? / Everyone you meet gently hugged you, / Are you still spinning around him?) [20, p. 10].

In poems about love, the poet not only conveys positive emotions and joyful events with rhetorical questions. Through rhetorical figures, a feeling of fleeting love, doubt or anxiety, betrayal or separation from a loved one is also conveyed. The questions capture the memories of the lyrical hero, for example, about his first lover, with whom he parted long ago. 
In the poet's landscape poetry, the methods of rhetorical appeals play a role in personifying the inanimate world of nature. Lyrics of S.S. Vasilyev convinces the reader that the man is indeed a part of nature. The poet conveys never-ending love for his native land, sincere feelings for the preservation of the environment.

Appeals and questions of this kind indicate that the author's natural phenomena are always depicted in an animated and humanized form. It should be noted that in love and the landscape lyrics, rhetorical figures become lyrical appeals addressed to objects of the surrounding world, natural phenomena, a beloved girl or even an abstract category - without an addressee, and are written in the form of a lyric monologue of the poet.

The techniques of lyrical addresses and questions are used in works with a philosophical sound, written by the poet in the 1950s. Eternal questions about the meaning and significance of human life, about the relationship of people in society, etc. are rethought by the poet. In poems, the author raises questions that worry him, waiting for a response to them, but cannot find an answer. The lyrical hero asks himself a question, since the absence of an addressee is most specific for philosophical lyrics.

The poems Kapsaer ere (Tell me), Aar bayakh tiitim (My majestic larch) are rich in rhetorical questions addressed to abstract concepts and natural objects such as happiness, love, grief, thicket, mountains, trees, the Lena River etc. Nature, the environment involuntarily become interlocutors of the lyrical hero immersed in various thoughts. Syntactic figures in philosophical works, in particular, rhetorical questions contribute to the transfer of the experiences of the lyric hero, and also help to attract the attention of the reader, inviting him for joint reflections and thoughts.

The satirical poems by S.S. Vasilyev are filled with rhetorical appeals as well. They expose the shortcomings of social development and inept management of power by society, an indifferent attitude towards the people, and also ridicule the negative features of people. In the poems Ygyllybyt dyardyamalar (Scattered remains), Khoyutanap (Khoyutanovu), Suottuluur suol (The road to Sottintsy), etc. other objects of ironic appeals are the heroes who are condemned by the author.

The works of S.S. Vasilyev, which have a satirical content, consist of the author's introduction and conclusion, and the main part is created by the poet in the form of a dialogue. In some cases, it is given in the form of a monologue by the author, presented in the form of rhetorical addresses and questions. Thus, the author raises the main problem. The techniques of rhetoric are used to reveal the ideological concept of the author and to strengthen the problematics of the work.

It is known that the main task of exclamation addresses in poetry is aimed at conveying the emotional sound and high intonation of the work. Poems representing the journalistic lyrics of S.S. Vasilyev are distinguished by high pathos.

In his journalistic lyrics, the exclamation points out the main author's position and the ideological content of the work. Using various exclamation phrases, the poet expresses his emotions: joy, admiration, and pride. In these poems, the author glorifies a man of labor, foremost workers, warriors-defenders of the fatherland, describes the dynamic development of society, the construction of cities and villages, and technical progress.

The ballad Sacred Ilmen is considered an example of the most vivid and expressive use of various means of syntactic figures. The work is filled with repetitions, antitheses, syntactic parallelism. In addition, the ballad is written in verses, consisting of interrogative and exclamatory sentences, which convey the poet's excitement and grief for the dead soldiers, reveal its main content, filled with lofty patriotic thoughts.

The poet's heartbreak and sincere cry for the dead compatriots - the defenders of the homeland - are conveyed by rhetorical methods, i.e. repetition questions and refrains. The poet's rhetorical questions are given in an extended form and cover several poetic parallel lines consisting of sentences identical in syntax.

By rhetorical appeals, presented by parallel stanza constructions, the author makes the facts of tragic events more specific and focuses the reader's attention on the depiction of the heroic feat of Yakutian soldiers in the war. With the help of a lyrical appeal to the sacred lake Ilmen, a picture of a terrible tragedy is recreated, the patriotic motive of the work is strengthened - the main characteristic feature of the poet's journalistic lyrics. In the work, the figures of poetic syntax perform a pictorial and expressive function, in addition, they ensure the harmony of the composition of the poem.

\section{Conclusion}

Thus, the techniques of poetic syntax are distinguished by a variety of functions and stylistic possibilities. S.S. Vasilyev, on the basis of expressive means of poetic syntax, creates memorable poetic and more artistic images. Syntactic techniques play an important role in the disclosure and coverage of the topic, contribute to the creation of lyrical digressions, and serve as the basis for creating a verse of poetic texts. In the embodiment of artistic images and the ideological concept of a work, rhetorical figures and various types of repetitions play an important role. Parallelisms and refrains act as a means of building the composition of the text and testify to the folklorism of the poet's works.

\section{References}

1. M.M. Bakhtin, Aesthetics of verbal creativity 2nd ed (Iskusstvo, Moscow, 1986).

2. G.O. Vinokur, Russian literature: from the theory of literature to the structure of the text. Anthology (Akademiya, Moscow, 1997).

3. A.A. Lebedev, Poetic syntax of P.A. Vyazemsky (St. Petersburg, 2016). 
4. P. Sivtceva - Maksimova, E. Rufova, Ep SBS 144, 1251-1257. Doi: 10.15405/epsbs.2020.08.144 (2020).

5. P. V. Sivtseva-Maksimova. J of Hist. Cult. and Art Research, 7 (3), 293-301. (2018). https://doi.org/10.7596/taksad.v7i3.1732

6. N.Z. Kopyrin, Өлбөт өрөгөй (Poet Sergei Vasiliev ol5o, Ylete, ayimnyyta) (Yakutsk, 2007).

7. N.N. Toburokov, Olonkho - the spiritual heritage of the Sakha people: Collection of scientific articles. (IHS AS RS (Y), Yakutsk 2000).

8. M.N. Dyachkovskaya, Alliteration and rhyme in Yakut poetry. Evolution and classification problems. (Publishing house of Siberian branch, Novosibirsk, 1998).

9. A.P. Kvyatkovsky, Poetic Dictionary 3rd ed., Rev. and add. (RSHU, Moscow, 2013).

10. S.S. Vasilyev, Selected works in two volumes T.I (Yakutknigoizdat, Yakutsk, 1966).

11. S.S. Vasilyev-Borogonsky, Syrekh ylyyr: Hohoonnor (Kinige publishing house, Yakutskai, 1969).

12. V.V. Illarionov, Olonkho - the spiritual heritage of the Sakha people: Collection of scientific articles. (IHS AS RS (Y), Yakutsk, 2000).

13. I. V. Sobakina, T. I. Petrova. J of Hist. Cult. and Art Research, 7 (3), 302-317. https://doi.org/10.7596/taksad.v7i3.1733 (2018).

14. Yu. P. Borisov, New Research of Tuva, 4, 250260 (In Russ.). DOI: www.doi.org/10.25178/nit.2020.4.17 (2020).

15. Yu. P. Borisov. Scientific dialog, 10, 213-230. DOI: 10.24224 / 2227-1295-2020-10-213-230 (In Russ.) (2020).

16. S.S. Vasilyev. Selected works in two volumes T. II (Yakutknigoizdat, Yakutsk, 1967).

17. S.S. Vasilyev. Olbet өregey: Hohoonnor, poemalar (Kinige publishing house, Yakutskay, 1988).

18. S.S. Vasilyev. Pole Star, 1, January-February (1968)

19. L.E. Manchurina. Sergei Vasilyev-Borogonsky: the poet is a citizen (IHS AS RS (Y), Yakutsk, 2007)

20. S.S. Vasilyev. When autumn comes ...: verses, poems (Bichik, Yakutsk, 2007). 